\title{
Melanoma of the Ciliary Body and Choroid pTX TNM Finding v7
}

National Cancer Institute

\section{Source}

National Cancer Institute. Melanoma of the Ciliary Body and Choroid PTX TNM Finding v7. NCI Thesaurus. Code C88684.

Melanoma of the ciliary body and choroid in which the primary tumor cannot be assessed. (from AJCC 7th Ed.) 